\title{
ХРОНИКА
}

\section{9-е научные чтения памяти П.Н. Чирвинского}

\section{И.Я. Илалтдинов}

Пермский государственный национальный исследовательский университет, 614990, Пермь, ул. Букирева, 15. E-mail: mineral@psu.ru

(Статья поступила в редакциюю 1 февраля 2017 г.)

В Пермском государственном национальном исследовательском университете проведены ежегодные научные чтения памяти П.Н. Чирвинского с международным участием. Рассмотрены проблемы минералогии, петрологии, литологии, металлогении и геохимии, опубликованы материалы конференции.

Ключевые слова: научные чтения, доклад, минералогия, металлогения. DOI: 10.17072/psu.geol.16.1.91

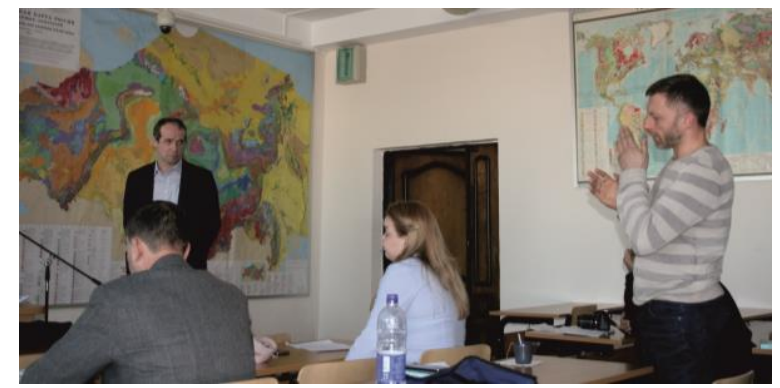

31 января 2017 г. на кафедре минералогии и петрографии состоялись ежегодные научные чтения памяти П.Н. Чирвинского. С докладами выступили ученые, преподаватели, аспиранты, магистры и студенты Пермского национального исследовательского университета, Горного института УрО РАН (г. Пермь), Института геологии и геохимии им. А.Н. Заварицкого УрО РАН (г. Екатеринбург), Института геологии УНЦ РАН и Института проблем сверхпластичности металлов (г. Уфа), АО «ВНИИХТ» и ФГУП «ВИМС» (г. Москва), ФГУП «ЦНИИГеолнеруд» (г. Казань). Были представлены доклады российских ученых с участием зарубежных коллег из Университета города Гранада (Испания) и Института геологии Инсбрукского университета (Австрия).

Следует отметить обстоятельные и содержательные выступления докторов геолого-минералогических наук Д.Е. Савельева и И.И. Чайковского.

Д.Е. Савельев, традиционно занимающийся исследованием хромшпинелидов ультраосновных массивов Южного Урала, с соавтором из Института проблем сверхпластичных металлов РАН С.Н. Сергеевым в своем докладе привёл описание морфологии и состава акцессорных и рудообразующих хромшпинелидов из недостаточно изученного в этом плане Аккаргинского массива ультрамафитов юговосточной части Южного Урала. Им сделан вывод о том, что ультрамафиты изученного района представляли собой материал мантийного клина, пронизанный интрузиями островодужного типа.

И.И. Чайковский всегда отличался в своих научных познаниях новым взглядом на, казалось бы, устоявшиеся вещи. В своем докладе совместно с коллегами по Горному институту УрО РАН Е.П. Чирковой и О.В. Коротченковой он изложил новый взгляд на формирование структуры калийной залежи Старобинского месторождения Республики Беларусь на основе изучения эпигенетических процессов и минералов.

Достаточно интересно выглядели результаты экспериментальных исследований по гидросепарации тяжелой фракции с выделением ультраконцентрата и его последующего изучения с применением электронного микроскопа, представленные магистрантами кафедры минералогии и петрографии О.В. Аликиным, А.А. Горбуновым, Д.Ф. Хасиятовым.

Проблемам петрологии и литологии были посвящены доклады сотрудников 
Института геологии и геохимии им. А.Н. Заварицкого Е.А. Зиньковой и О.Ю. Мельничука. Е.А. Зинькова рассказала об изучении изотопного состава и возраста цирконов из редкой разновидности пород среди гранитоидов Верхисетского массива - мусковит-гранатовых лейкогранитов Соколиного Камня, формировавшихся в связи с ранним эпизодом коллизионного магматизма. Датирование цирконов выполнено в лаборатории IBERSIMS университета Гранады (Испания) соавторами доклада П. Монтеро и Ф. Беа.

О.Ю. Мельничук в своем докладе затронул проблему источников питания песчаников кодинской свиты позднего девона на Среднем Урале. На основе сравнительного анализа петрографических и геохимических особенностей верхнефранских песчаников нижней подсвиты биягодинской свиты Южного Урала и кодинской свиты Среднего Урала сделано предположение о существовании микроконтинента в позднедевонское время в пределах Восточно-Уральской мегазоны.

Значительная часть докладов научных чтений была посвящена проблемам металлогении. Заведующий кафедрой минералогии и петрографии Р.Г. Ибламинов проанализировал развитие и становление нового научного направления - минерагеодинамики - в трудах ученых кафедры с момента ее основания по настоящее время. Основная заслуга в формировании минерагеодинамики как нового научного направления принадлежит Р.Г. Ибламинову, изложившему его фундаментальные основы в докторской диссертации и впоследствии в учебном пособии «Минерагения (основы минерагеодинамики)».

Оценка перспектив золотого оруденения в углеродистых сланцах на восточном склоне Южного Урала была дана в докладе научного сотрудника Института геологии УНЦ РАН А.В. Сначева.

Серия студенческих докладов под руководством докторов геолого-минералогических наук В.А. Наумова и О.Б. Наумовой была посвящена изучению россыпного золота в различных месторождениях республик Хакасия и Тыва.

Весьма разнообразными по тематике и не менее интересными были доклады о проблемах геохимии, в частности, доклад сотрудников Горного института УрО РАН Б.А. Бачурина и Т.А. Одинцовой о методических особенностях изучения органического вещества солей.

Завершились чтения совместным чаепитием в дружеской, теплой атмосфере на кафедре минералогии и петрографии. По материалам докладов был издан сборник, в котором опубликована 41 статья 84 авторов (Проблемы ..., 2017).

\section{Библиографический список}

Проблемь минералогии, петрографии и металлогении: науч. чтения памяти П.Н. Чирвинского: сб. науч. ст. / Перм. гос. нац. исслед. ун-т. Пермь, 2017. Вып. 20. 303 с.

\section{$19^{\text {th }}$ Scientific Readings Devoted to P.N. Chirvinskiy}

\section{I.Ya. Ilaltdinov}

\section{Perm State University, 15 Bukireva Str., Perm 614990, Russia}

Scientific conference devoted to P.N. Chirvinskiy was held in the Perm State University (January 2017). The problems of mineralogy, petrology, lithology, metallogeny and geochemistry were discussed.

Key words: geological conference, report, mineralogy, metallogeny.

\section{References}

Problemy mineralogii, petrografii i metallogenii [The problems of mineralogy, petrography and metallogeny]. Nauch. chteniya pamyati
P.N.Chirvinskogo: sbornik nauchnykh statey. Perm. Gos. Nats. Issled. Univ., Perm, 2017, Vyp. 20. p. 303. (in Russian). 